\title{
Access to Safe Drinking Water in Developing Countries: A Comparative Analysis of the Urban and Rural Areas of Zaria, Kaduna State, Nigeria
}

\section{1*IDUSERI, EO; ${ }^{2}$ ABBAS, II; ${ }^{3}$ IZUNOBI, JU; ${ }^{4}$ OGEDEGBE, SO; ${ }^{5}$ OGBONNA, DO}

\author{
${ }^{1}$ Department of Environmental Science, National Open University of Nigeria, Abuja, Nigeria \\ ${ }^{2}$ Department of Geography, Kaduna State University, Kaduna, Nigeria \\ ${ }^{3}$ Department of Chemistry, University of Lagos, Akoka-Yaba, Lagos, Nigeria \\ ${ }^{4}$ Department of Geography, College of Education, Igueben, Edo State, Nigeria \\ ${ }^{5}$ Department of Geography \& Environmental Management, Ahmadu Bello University, Zaria, Kaduna State, Nigeria \\ *Corresponding Author Email: iemily@noun.edu.ng
}

\begin{abstract}
Water is a "sin qua non" for virtually all human activities; a pre-requisite for sustainable development as the consequences of safe water for health, productivity and quality of life as well as implications for economic development are enormous. This study investigated the sources of water supply and challenges faced by inhabitants in accessing these water sources in three districts each of urban and rural Zaria, Nigeria, and compared the results. Descriptive statistics and average mean score (AMS) technique was applied, and requisite data presented in frequency and percentage tables. The results revealed that the urban dwellers had to travel longer distances, than the rural dwellers, to source water and that the sources of water supply varied with the season. Whilst the urban areas accessed wells and water vendors in the wet and dry seasons, respectively, for non-domestic water supply and water vendors for domestic water supply; all year round, residents of the rural areas sourced non-domestic water supply from rainfall in the rainy season and streams in the dry season. Conversely, wells and water vendors were accessed in the wet and dry seasons, respectively, for rural domestic water supply. The corollary is that water vendors and wells are the predominant sources of water in Zaria, Nigeria. The methods of water purification employed by the communities sampled and their challenges to safe and adequate water supply are discussed; and plausible solutions are proffered. In addition, some recommendations to mitigate poor access to water are also volunteered.
\end{abstract}

\section{DOI:https://dx.doi.org/10.4314/jasem.v25i11.4}

Copyright: Copyright $\odot 2021$ Iduseri et al. This is an open access article distributed under the Creative Commons Attribution License (CCL), which permits unrestricted use, distribution, and reproduction in any medium, provided the original work is properly cited.

Dates: Received: 22 August 2021; Revised: 17 September 2021; Accepted: 06 October 2021

Keywords: groundwater, rural-urban dichotomy, water management, water policy, water resources

Water is, undoubtedly, the sine qua non of life and has, from time immemorial, been a decisive factor in man's survival in terms of economic and social activities, including farming and animal husbandry, domestic consumption and, to some extent, transportation, etc. (Ahile et al., 2015). Water can be also described as the lifeline of the biosphere but it is not uniformly distributed and demand for it remains greater than the available supply in many regions of the world (Falkenmark and Rockstrom, 2004). Nevertheless, an adequate, reliable, clean, accessible, acceptable and safe source of water supply should be available (Bos et al., 2016). In the developing world, water infrastructure is poor and many people do not have access to potable water and where available, clean and safe drinking water is inadequate for human consumption and other uses, such as for domestic and agricultural purposes (Cosgrove and Loucks, 2015). Consequently, in as much as water is an essential component of the planetary life support system, water deficiency constitutes an insecurity that has to be overcome in the process of socio-economic development (Falkenmark, 2013). The problem of potable water shortage has become a source of concern in the world; locally and globally, underpinned by the United Nations Sustainable Development Goals 6 (SDG-6) geared at providing access to clean drinking water for all and highlighting its importance to hygiene and the prevention of diseases (www.un.org). Despite these, inequalities remain in accessing safe drinking water in the world (Schyns et al., 2015). In some countries, sufficient freshwater is not available (physical scarcity) whereas in other countries, abundant freshwater is available but expensive to use (economic scarcity). According to the World Bank (1996), about 80 countries suffer water shortages and this is reflected in their health and economies whereas more than two billion people have no access to clean water (UNESCO, 2016). Water is necessary to support socio-economic activities and maintain healthy ecosystems. In Nigeria, water scarcity existed as far back as the pre-colonial period when people had to 
migrate from one part of the country to another in search of water. It is notable that only $27.4 \%$ of the total population of the country had access to improved water supply in 1974; with the rural population accounting for not more than $0.30 \%$ (Nura and Sabo, 2011). Water shortages are due to a mismatch between demand for water and its availability. Throughout history, many communities have adapted to water shortages by transforming terrestrial water systems (L'Vovich et al., 1990). In many places, water scarcity increases as water systems are subjected to rises in pollution and exploitations (Postel et al., 1996; Postel, 2000). People in the slums of developing countries are reported to, typically, pay 5-10 times more per unit of water than people, in the urban areas, with access to pipe-borne water ( $\mathrm{Xu}$ and Usher, 2006). Water scarcity is a relative concept and can occur at any level of supply or demand (UN-Water, 2006). For an individual to be water secure, for instance, the individual needs about $1200 \mathrm{~m}^{3}$ of water per annum (Allan, 2010). Scarcity may also be a social construct (a product of affluence, expectations and customary behaviour) or the consequence of altered supply patterns, stemming from climate change (UN, 2011). Ahile et al. (2015) conducted a study on the coping strategies of residents with water scarcity in Makurdi town, Nigeria and their data revealed an estimated total household water demand of 127,600 litres per day relative to the available supply of 40,520 litres per day; with a shortfall of 87,080 litres per day translating to about $68.2 \%$ of the water demand remaining unsupplied. Bello and Tuna (2014) also evaluated the demand and supply of portable water in Kano, Nigeria by collecting secondary data from several water supply-related institutions and determined that water supply in Kano did not meet demand due to insufficient numbers of water treatment plants, power failure and shortage of funds, amongst others.

This study assesses the sources, spatial distribution and water availability as well as quantifies the demand, supply and consumption per household in the urban and rural areas of Zaria, Kaduna State, Nigeria.

\section{MATERIALS AND METHODS}

Description of the study area: Zaria (Zazzau) in Kaduna State is located on the vast undulating plains of Northern Nigeria (Figure 1). It presently cuts across four local government areas, viz: Sabon-Gari, Zaria, Giwa and Soba, and it is located at latitude $11^{\circ} 5^{\prime} 82^{\prime \prime}$ $\mathrm{N}$ and longitude $7^{\circ} 43^{\prime} 12^{\prime \prime} \mathrm{E}$. Zaria experiences two distinct (wet and dry) seasons, which are caused by the movement of the Inter-Tropical Discontinuity (ITD) under the influence of two major air masses namely the tropical continental (cT) and tropical maritime (mT). It has a mean annual rainfall of about $800 \mathrm{~mm}$, mainly witnessed in the wet season (April-October), with temperatures ranging between 21-29 ${ }^{\circ} \mathrm{C}$ throughout the year (Yakubu, 2013). Zaria is drained majorly by the Galma River with three other rivers as its tributaries: Rivers Kubanni, Shika and Saye.

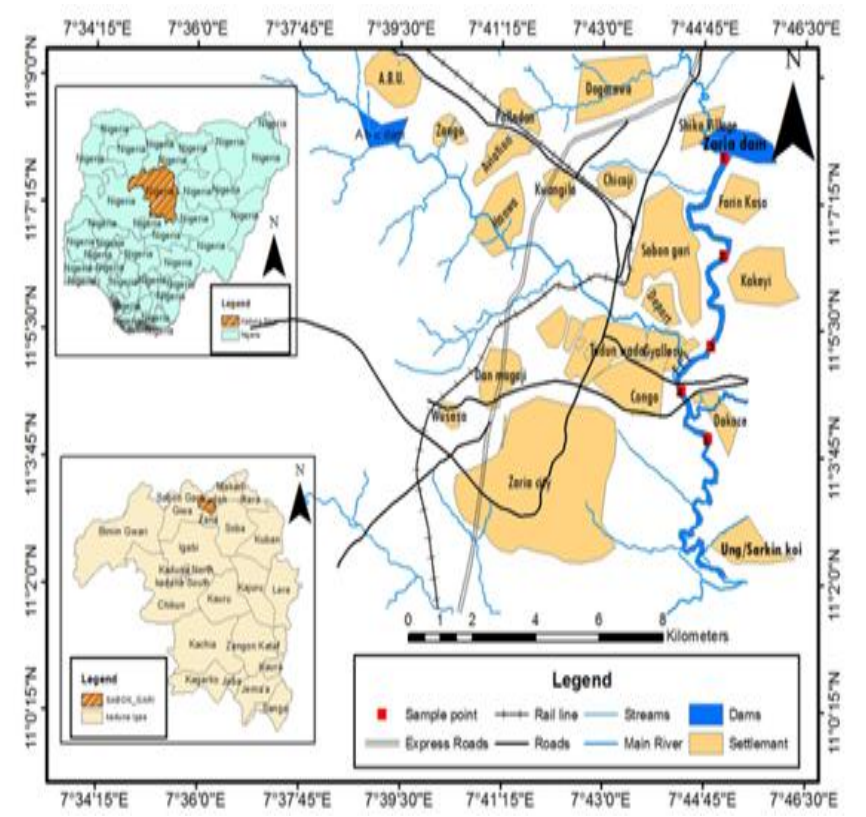

Fig 1: Map of Zaria (Adapted from the Administrative Map of Kaduna State, 2019)

The estimated total population of Zaria in 2019 was 719,000 (WPR, 2021). The growth of the region is attributed partly to history and the establishment of higher educational institutions, such as Ahmadu Bello 
University, College of Aviation Technology, Federal College of Education and other research institutes as well as industries, such as the Nigerian Tobacco Company and Nigerian Oil Mills. Zaria is made up of four distinct residential and commercial areas: the old walled city, the Colonial Township or Sabon-Gari, Tudun-Wada and Samaru. It also consists of many rural settlements; with predominant socio-economic activities of farming and cattle rearing. The old city has served as a political, administrative and market centre for several years and the chief expression of these functions are linked with the Emir's palace.

Data collection and analysis: The data required for the study were collected from primary and secondary sources. Questionnaires and interviews were the instruments for eliciting information. The questionnaire was prepared with answer options in a 5-point Likert scale, delineated in Table 1. The questionnaire elicited information on the social and demographic characteristics of respondents as well as the four research questions raised herein. Detailed and guided interviews were also used to get necessary and basic information where necessary. The data was analysed statistically and null hypotheses were tested at the end of the investigation to address the research questions.

\begin{tabular}{lll}
\multicolumn{3}{c}{ Table 1: Likert scale } \\
\hline Option & Code & Point \\
\hline Strongly Agree & SA & 5 \\
Agree & A & 4 \\
Disagree & D & 3 \\
Strongly Disagree & SD & 2 \\
Undecided & UD & 1 \\
\hline
\end{tabular}

Data are presented in frequency and percentage tables. The average mean score (AMS) technique was used to test the hypothesis. The derived value (DV) was obtained from the average of all the scale points (1-5) thus:

$$
\mathrm{DV}=\frac{5+4+3+2+1}{5}=\frac{15}{5}=3
$$

The computed value was obtained from a summation of the frequency multiplied by the scale point and divided by the summation of the frequency, according to equation 1 .

$$
\mathrm{CV}=\frac{\sum f x}{\sum f}
$$

where $f=$ frequency and $x=$ scale point

The computed values (CV) were also compared to the derived values (DV) of 3.0. When $\mathrm{CV}$ is greater than
DV, then the answer was regarded as positive but negative when CV is less than DV. Similarly, null hypotheses were rejected when $\mathrm{CV}$ was greater than DV, and accepted when CV was less than DV.

\section{RESULTS AND DISCUSSION}

The sample size for the respondents in the selected three urban and rural areas each of Zaria was calculated as 384 at a $95 \%$ confidence level and 5\% margin of error (Krejcie and Morgan, 1970), based on a total population of 719,000 (WPR, 2021) but was rounded-up to a sample size of 400 , for this study. The questionnaires were distributed and retrieved as shown in Table 2. Tudun-Wada got the highest number of respondents of 160 whereas Sakadadi had 12 participants. It is worthy of note that the more populated areas of Tudun-Wada, Sabon-Gari and Samaru are urban settlements while the less densely populated areas of Kuffena, Wusasa and Sakadadi are rural.

Table 2: Distribution of questionnaires based on the population of selected communities in the study area

\begin{tabular}{lll}
\hline Community & ${ }^{a}$ Total Population & Sample Selection \\
\hline Samaru & 162,519 & 70 \\
Sabon-Gari & 56,175 & 93 \\
Tudun-Wada & 436,811 & 160 \\
Kuffena & 28,886 & 40 \\
Wusasa & 17,737 & 25 \\
Sakadadi & 16,872 & 12 \\
Total & $\mathbf{7 1 9 , 0 0 0}$ & $\mathbf{4 0 0}$ \\
${ }^{\text {a }}$ Source: www.macrotrends.net (Nigeria Metro Area Population \\
\multicolumn{2}{c}{$1950-2020)$}
\end{tabular}

In Table 3, a breakdown of the social demographics of the respondents involved in the study is enumerated. The analysis showed that there were more females $(58 \%)$ than males and more indigenes $(53 \%)$ than nonindigenes. Conversely, $70 \%$ of the respondents were married with more than one-third of the households catering for $10-14$ persons. Almost $50 \%$ of the people sampled had tertiary education whereas close to $80 \%$ were in the 29-49-year age bracket. The relatively high numbers of post-primary and tertiary education level respondents were attributed to the university towns of Samaru and Tudun-Wada. This is also a pointer to the robustness of the responses received. Table 4 shows the distances travelled by Zaria residents to access water in the dry and wet seasons, respectively. It indicates that the respondents in the urban areas travelled distances of between 1-5 km, or over, occasionally, to get water in the dry and wet seasons whereas those in the rural areas did not have to travel as far because of nearby natural sources, such as rivers and streams. In rural areas, for instance, the respondents in Kuffena travelled $<4 \mathrm{~km}$ in the rainy season but $>4 \mathrm{~km}$ in the dry season. The situation is similar across the rural areas, where longer distances 
were, explicably, travelled in the dry season, to access water. Relatively longer distances were travelled in both rural and urban communities in the dry season. Whilst close to $50 \%$ of the residents in the Zaria area travelled less than $1 \mathrm{~km}$ in the rainy season, over $50 \%$ travelled up to $2 \mathrm{~km}$, in dry season, to access water. This is attributable to the scarcity of water typically experienced in the dry season, where alternative nonnatural sources of water do not exist (UN-Water,
2007). Ezenwaji et al. (2014) has highlighted a Federal Ministry of Water Resources' 2008 survey, which showed that about $80 \%$ of residents in Nigeria lacked access to improved drinking water. The global assessment of water supply and sanitation data describes reasonable access to water as being the availability of at least 20 litres per person per day from a source within $1 \mathrm{~km}$ of the user's dwelling (Ward and Robinson, 2000; WHO/UNICEF, 2000).

Table 3: Demographics of the respondents

\begin{tabular}{|c|c|c|c|c|c|}
\hline & Frequency & Percentage $(\%)$ & & Frequency & Percentage (\%) \\
\hline Sex & \multicolumn{5}{|c|}{ Household Size (persons) } \\
\hline Female & 230 & 58 & $>5$ & 70 & 17 \\
\hline Male & 170 & 42 & $5-9$ & 50 & 13 \\
\hline Total & 400 & 100 & $10-14$ & 140 & 35 \\
\hline Age (years) & & & $15-19$ & 100 & 25 \\
\hline $18-28$ & 60 & 15 & $20-29$ & 40 & 10 \\
\hline $29-39$ & 150 & 38 & Total & 400 & 100 \\
\hline $40-49$ & 160 & 40 & Level of Education & & \\
\hline$>50$ & 30 & 7 & None & 30 & 7.5 \\
\hline Total & 400 & 100 & Quran School & 40 & 10 \\
\hline Marital Status & & & Primary School & 30 & 7.5 \\
\hline Married & 280 & 70 & Post-Primary School & 120 & 30 \\
\hline Single & 50 & 13 & Tertiary Education & 180 & 45 \\
\hline Divorced & 40 & 10 & Total & 400 & 100 \\
\hline Separated & 30 & 7 & & & \\
\hline Total & 400 & 100 & & & \\
\hline \multicolumn{6}{|c|}{ Habitation Status } \\
\hline Indigene & 212 & 53 & & & \\
\hline Migrant & 188 & 47 & & & \\
\hline Total & 400 & 100 & & & \\
\hline
\end{tabular}

This however does not mean that 20 litres per person per day is a recommended quantity of water for daily use. Oyebande (2001) has opined that an assured supply of water, both qualitatively and quantitatively, for the purposes of consumption, hygiene and amenity use, greatly improves the social and economic activities of people. As a result, water supply and its efficient use and sustainability are of grave importance to any nation, especially the LMICs. Table 5 shows the daily water demands of the communities in the Zaria study area. As expected, the urban communities made more demands on water than the rural communities. This may be attributable to the larger population in the urban area but it must be recalled that they also travelled longer distances ( $c f$. Table 4) and may be, therefore, hoarding. Similarly, the demand was generally higher in the dry season. It is interesting to note that whilst 151-200 litres were the minimum daily water demand in the rural areas, two of the urban communities sampled made a daily demand of less than 50 litres. The different water sources in the Zaria area are collated in Table 6. More residents accessed streams, taps, burrow pits, water trucks and water vendors in the dry season whereas wells, boreholes and rainfall were the main sources of water for the rural and urban communities in the wet season. It is also interesting to note that while more urban dwellers relied most on water vendors for water, most respondents in the rural settlements relied on rainfall. Nonetheless, wells are an important source of water, in the rainy season, in both rural and urban areas. Pertinently, well water was the only source of water available all year around in all the communities sampled. It is also notable that respondents reported that water was not collected from rainfall and burrow pits in the dry and wet seasons, respectively. Furthermore, Sabon-Gari residents accessed boreholes more in the dry season than wet season; contrary to what was observed in the five other settlements. Residents of Wusasa and Sakadadi reported that they lacked boreholes and tap water, with Sakadadi also unable to access water trucks. Surprisingly, Sakadadi, Sabon-Gari and Tudun-Wada residents did not get water from the streams in the rainy season whereas water vendors and trucks did not provide water in Kuffena in the wet season. In addition, Samaru, Kuffena and Wusasa accessed streams in both seasons. In the rural areas, tap water and burrow pits did not deliver water in the wet season whereas streams, wells, burrowed pits and water vendors provided water during the dry season. The data for domestic water supply in the Zaria area is shown in Table 7. 
Table 4: Distances to sources of water supply

\begin{tabular}{|c|c|c|c|c|c|c|c|c|c|c|c|c|c|c|c|c|c|c|}
\hline \multirow{3}{*}{$\begin{array}{l}\text { Distance } \\
\text { (Km) }\end{array}$} & \multicolumn{8}{|c|}{ Urban Communities } & \multicolumn{8}{|c|}{ Rural Communities } & \multicolumn{2}{|c|}{ Total } \\
\hline & \multicolumn{2}{|c|}{ Samaru } & \multicolumn{2}{|c|}{ Sabon-Gari } & \multicolumn{2}{|c|}{ Tudun-Wada } & \multicolumn{2}{|c|}{ Sub-Total } & \multicolumn{2}{|c|}{ Kuffena } & \multicolumn{2}{|c|}{ Wusasa } & \multicolumn{2}{|c|}{ Sakadadi } & \multicolumn{2}{|c|}{ Sub-Total } & \\
\hline & DS & WS & DS & WS & DS & WS & DS & WS & DS & WS & DS & WS & DS & WS & DS & WS & DS & WS \\
\hline$\leq 1.0$ & 10 & 30 & 33 & 40 & 52 & 84 & 95 & 154 & 4 & 20 & 2 & 14 & 0 & 6 & 6 & 40 & 101 & 194 \\
\hline $1.1-2.0$ & 20 & 22 & 20 & 23 & 24 & 38 & 64 & 83 & 6 & 0 & 3 & 3 & 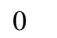 & 3 & 0 & 15 & 73 & 98 \\
\hline 2.1-3.0 & 10 & 10 & 11 & 16 & 36 & 25 & 57 & 51 & 13 & 7 & 3 & 2 & 2 & 3 & 18 & 12 & 75 & 63 \\
\hline $3.1-4.0$ & 12 & 4 & 15 & 8 & 35 & 6 & 62 & 18 & 7 & 4 & 4 & 2 & 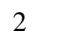 & 0 & 13 & 6 & 75 & 24 \\
\hline $4.1-5.0$ & 10 & 2 & 8 & 4 & 9 & 3 & 27 & 9 & 2 & 0 & 6 & 2 & 4 & 0 & 12 & 2 & 39 & 11 \\
\hline$\geq \mathbf{5 . 0}$ & 8 & 2 & 6 & 2 & 4 & 4 & 18 & 8 & 8 & 0 & 7 & 2 & 4 & 0 & 19 & 2 & 37 & 10 \\
\hline
\end{tabular}

Table 5: Water demand per day in the study area

\begin{tabular}{|c|c|c|c|c|c|c|c|c|c|c|c|c|c|c|c|c|c|c|}
\hline \multirow{3}{*}{$\begin{array}{l}\text { Capacity } \\
\text { (Litres) }\end{array}$} & \multicolumn{8}{|c|}{ Urban Communities } & \multicolumn{8}{|c|}{ Rural Communities } & \multicolumn{2}{|c|}{ Total } \\
\hline & \multicolumn{2}{|c|}{ Samaru } & \multicolumn{2}{|c|}{ Sabon-Gari } & \multicolumn{2}{|c|}{ Tudun-Wada } & \multicolumn{2}{|c|}{ Sub-Total } & \multicolumn{2}{|c|}{ Kuffena } & \multicolumn{2}{|c|}{ Wusasa } & \multicolumn{2}{|c|}{ Sakadadi } & \multicolumn{2}{|c|}{ Sub-Total } & \multirow[b]{2}{*}{ DS } & \multirow[b]{2}{*}{ WS } \\
\hline & DS & WS & DS & WS & DS & WS & DS & WS & DS & WS & DS & WS & DS & WS & DS & WS & & \\
\hline$<50$ & 0 & 0 & 2 & 1 & 1 & 3 & 3 & 4 & 0 & 0 & 0 & 0 & 0 & 0 & 0 & 0 & 3 & 4 \\
\hline $51-100$ & 5 & 10 & 12 & 18 & 4 & 10 & 21 & 38 & 0 & 0 & 0 & 0 & 0 & 0 & 0 & 0 & 21 & 38 \\
\hline $101-150$ & 15 & 20 & 20 & 20 & 13 & 15 & 48 & 55 & 0 & 0 & 0 & 0 & 0 & 0 & 0 & 0 & 48 & 55 \\
\hline $151-200$ & 12 & 19 & 26 & 25 & 16 & 34 & 54 & 78 & 4 & 8 & 3 & 3 & 0 & 0 & 7 & 11 & 61 & 89 \\
\hline $201-250$ & 26 & 11 & 31 & 23 & 73 & 50 & 130 & 84 & 20 & 18 & 4 & 8 & 2 & 4 & 26 & 30 & 156 & 114 \\
\hline $251-300$ & 9 & 8 & 2 & 6 & 39 & 38 & 50 & 52 & 14 & 12 & 16 & 12 & 10 & 8 & 40 & 32 & 90 & 84 \\
\hline$>300$ & 3 & 2 & 0 & 0 & 14 & 10 & 17 & 12 & 2 & 2 & 2 & 2 & 0 & 0 & 4 & 4 & 21 & 16 \\
\hline Total & 70 & & 93 & & 160 & & 323 & & 40 & & 25 & & 12 & & 77 & & 400 & \\
\hline
\end{tabular}

Table 6: Sources of water supply

\begin{tabular}{|c|c|c|c|c|c|c|c|c|c|c|c|c|c|c|c|c|c|c|}
\hline \multirow[t]{2}{*}{ Communities } & \multicolumn{2}{|c|}{ Streams } & \multicolumn{2}{|c|}{ Well } & \multicolumn{2}{|c|}{ Bore Hole } & \multicolumn{2}{|c|}{ Rain } & \multicolumn{2}{|l|}{ Tap } & \multicolumn{2}{|c|}{ Burrow Pits } & \multicolumn{2}{|c|}{ Water Trucks } & \multicolumn{2}{|c|}{ Water Vendor } & \multicolumn{2}{|c|}{ Total } \\
\hline & DS & WS & DS & WS & DS & WS & DS & WS & DS & WS & DS & WS & DS & WS & DS & WS & DS & WS \\
\hline Urban & & & & & & & & & & & & & & & & & & \\
\hline Samaru & 10 & 3 & 10 & 3 & 10 & 20 & 0 & 8 & 5 & 5 & 3 & 0 & 12 & 11 & 20 & 20 & 70 & 70 \\
\hline Sabon-Gari & 8 & 0 & 8 & 50 & 7 & 4 & 0 & 18 & 5 & 5 & 0 & 0 & 30 & 7 & 34 & 9 & 93 & 93 \\
\hline Tudun-Wada & 12 & 0 & 20 & 70 & 10 & 30 & 0 & 20 & 8 & 8 & 0 & 0 & 25 & 18 & 85 & 14 & 160 & 160 \\
\hline Sub-Total & 30 & 3 & 38 & 123 & 27 & 54 & 0 & 46 & 18 & 18 & 3 & 0 & 67 & 36 & 139 & 43 & 323 & 323 \\
\hline Rural & & & & & & & & & & & & & & & & & & \\
\hline Kuffena & 8 & 4 & 5 & 10 & 6 & 12 & 0 & 14 & 2 & 0 & 4 & 0 & 6 & 0 & 9 & 0 & 40 & 40 \\
\hline Wusasa & 8 & 3 & 3 & 8 & 0 & 0 & 0 & 10 & 0 & 0 & 5 & 0 & 3 & 2 & 6 & 2 & 25 & 25 \\
\hline Sakadadi & 6 & 0 & 2 & 6 & 0 & 0 & 0 & 6 & 0 & 0 & 2 & 0 & 0 & 0 & 2 & 0 & 12 & 12 \\
\hline Sub-Total & 22 & 3 & 10 & 24 & 6 & 12 & 0 & 30 & 2 & 0 & 11 & 0 & 9 & 2 & 17 & 2 & 77 & 77 \\
\hline Total & 52 & 10 & 48 & 147 & 33 & 66 & $\mathbf{0}$ & 76 & 20 & 18 & 14 & $\mathbf{0}$ & 76 & 38 & 156 & 45 & 400 & 400 \\
\hline
\end{tabular}

*DS = Dry season, WS = Wet season 


\begin{tabular}{|c|c|c|c|c|c|c|c|c|c|c|c|c|c|c|c|c|c|c|}
\hline \multirow[t]{2}{*}{ Communities } & \multicolumn{2}{|c|}{ Streams } & \multicolumn{2}{|c|}{ Well } & \multicolumn{2}{|c|}{ Bore Hole } & \multicolumn{2}{|c|}{ Rain } & \multicolumn{2}{|l|}{ Tap } & \multicolumn{2}{|c|}{ Burrow Pits } & \multicolumn{2}{|c|}{ Water Trucks } & \multicolumn{2}{|c|}{ Water Vendor } & \multicolumn{2}{|l|}{ Total } \\
\hline & DS & WS & DS & WS & DS & WS & DS & WS & DS & WS & DS & WS & DS & WS & DS & WS & DS & WS \\
\hline Urban & & & & & & & & & & & & & & & & & & \\
\hline Samaru & 0 & 0 & 0 & 6 & 16 & 10 & 0 & 8 & 4 & 8 & 0 & 0 & 20 & 20 & 30 & 18 & 70 & 70 \\
\hline Sabon-Gari & 0 & 0 & 8 & 8 & 18 & 10 & 0 & 28 & 10 & 10 & 0 & 0 & 27 & 17 & 30 & 20 & 93 & 93 \\
\hline Tudun-Wada & 0 & 0 & 20 & 30 & 50 & 15 & 0 & 25 & 10 & 24 & 0 & 0 & 30 & 30 & 50 & 36 & 160 & 160 \\
\hline Sub-Total & 0 & 0 & 28 & 44 & 84 & 35 & 0 & 61 & 24 & 42 & 0 & 0 & 77 & 67 & 110 & 74 & 323 & 323 \\
\hline Rural & & & & & & & & & & & & & & & & & & \\
\hline Kuffena & 8 & 0 & 12 & 21 & 6 & 3 & 0 & 8 & 0 & 0 & 0 & 0 & 4 & 2 & 10 & 6 & 40 & 40 \\
\hline Wusasa & 8 & 0 & 4 & 12 & 0 & 0 & 0 & 7 & 0 & 0 & 0 & 0 & 4 & 3 & 9 & 3 & 25 & 25 \\
\hline Sakadadi & 2 & 0 & 4 & 9 & 0 & 0 & 0 & 0 & 0 & 0 & 0 & 0 & 3 & 0 & 3 & 3 & 12 & 12 \\
\hline Sub-Total & 18 & 0 & 20 & 42 & 6 & 3 & 0 & 15 & 0 & 0 & 0 & 0 & 11 & 5 & 22 & 12 & 77 & 77 \\
\hline Total & 18 & $\mathbf{0}$ & 48 & 86 & 90 & 38 & 0 & 76 & 24 & 42 & 0 & 0 & 88 & 72 & 132 & 86 & 400 & 400 \\
\hline
\end{tabular}

Table 8: Methods of purifying unsafe water

\begin{tabular}{|c|c|c|c|c|c|c|c|c|c|}
\hline \multirow[t]{2}{*}{ Method } & \multicolumn{2}{|c|}{ Urban Communities } & \multirow[b]{2}{*}{ Tudun-Wada } & \multirow[b]{2}{*}{ Sub-Total } & \multicolumn{2}{|c|}{ Rural Communities } & \multirow[b]{2}{*}{ Sakadadi } & \multirow[b]{2}{*}{ Sub-Total } & \multirow{2}{*}{ Total } \\
\hline & Samaru & Sabon-Gari & & & Kuffena & Wusasa & & & \\
\hline Use of Alum & 10 & 15 & 10 & 35 & 3 & 3 & 3 & 9 & 41 \\
\hline Boiling & 28 & 48 & 100 & 176 & 20 & 11 & 5 & 36 & 212 \\
\hline Filtration & 18 & 17 & 37 & 72 & 13 & 9 & 4 & 26 & 98 \\
\hline Decantation & 6 & 9 & 8 & 23 & 4 & 2 & 0 & 6 & 29 \\
\hline Use of iodine solution/tablets/crystals & 0 & 0 & 0 & 0 & 0 & 0 & 0 & 0 & 0 \\
\hline Use of chlorine & 8 & 4 & 5 & 17 & 0 & 0 & 0 & 0 & 17 \\
\hline Use of ultraviolet light & 0 & 0 & 0 & $\begin{array}{l}0 \\
323\end{array}$ & 0 & 0 & 0 & $\begin{array}{l}0 \\
77\end{array}$ & 0 \\
\hline Total & 70 & 93 & 160 & & 40 & 25 & 12 & & 400 \\
\hline
\end{tabular}

Table 9: Challenges to water supply in the study area

\begin{tabular}{|c|c|c|c|c|c|c|c|c|c|c|c|c|c|c|c|c|c|}
\hline \multirow{2}{*}{$\begin{array}{l}\text { Parameter } \\
\end{array}$} & \multicolumn{8}{|c|}{ Urban Communities } & \multicolumn{7}{|c|}{ Rural Communities } & \multirow{2}{*}{$\begin{array}{l}\text { Remark } \\
\text { DV = 3 }\end{array}$} & \multirow{2}{*}{ Decision } \\
\hline & & SA & A & D & SD & $\mathbf{U}$ & $\Sigma$ & $\mathrm{CV}$ & SA & A & D & SD & $\mathbf{U}$ & $\Sigma$ & $\mathrm{CV}$ & & \\
\hline \multirow{2}{*}{ Finance } & $f$ & 130 & 80 & 60 & 48 & 5 & 323 & & 47 & 13 & 7 & 5 & 5 & 77 & & & \\
\hline & $f x$ & 650 & 320 & 180 & 96 & 5 & 1251 & 3.87 & 235 & 52 & 21 & 10 & 5 & 323 & 4.19 & $\mathrm{CV}>\mathrm{DV}$ & 1 \\
\hline \multirow{2}{*}{ Distance } & $f$ & 165 & 94 & 40 & 20 & 4 & 323 & & 50 & 18 & 4 & 3 & 2 & 77 & & & \\
\hline & $f x$ & 825 & 376 & 120 & 40 & 4 & 1365 & 4.22 & 250 & 72 & 12 & 6 & 2 & 342 & 4.44 & $\mathrm{CV}>\mathrm{DV}$ & 1 \\
\hline \multirow[t]{2}{*}{ Season } & $f$ & 200 & 70 & 30 & 18 & 5 & 323 & & 68 & 5 & 2 & 1 & 1 & 77 & & & \\
\hline & $f x$ & 1000 & 280 & 90 & 36 & 5 & 1411 & 4.36 & 340 & 20 & 6 & 2 & 1 & 369 & 4.79 & $\mathrm{CV}>\mathrm{DV}$ & 1 \\
\hline \multirow[t]{2}{*}{ Lack of maintenance } & $f$ & 149 & 99 & 53 & 19 & 3 & 323 & & 51 & 12 & 7 & 5 & 2 & 77 & & & \\
\hline & $f x$ & 745 & 396 & 159 & 38 & 3 & 1314 & 4.15 & 255 & 48 & 21 & 10 & 2 & 336 & 4.36 & $\mathrm{CV}>\mathrm{DV}$ & 1 \\
\hline \multirow{2}{*}{ Inadequate government funding } & $f$ & 230 & 61 & 18 & 8 & 6 & 323 & & 51 & 12 & 7 & 5 & 2 & 77 & & & \\
\hline & $f x$ & 1150 & 244 & 54 & 16 & 6 & 1470 & 4.55 & 255 & 48 & 21 & 10 & 2 & 336 & 4.36 & $\mathrm{CV}>\mathrm{DV}$ & 1 \\
\hline Unseriousness of & $f$ & 192 & 80 & 30 & 16 & 5 & 323 & & 60 & 10 & 3 & 2 & 2 & 77 & & & \\
\hline Cooperation Staff & $f x$ & 960 & 320 & 90 & 32 & 5 & 1407 & 4.35 & 300 & 40 & 9 & 4 & 2 & 355 & 4.61 & $\mathrm{CV}>\mathrm{DV}$ & 1 \\
\hline \multirow{2}{*}{ Damaged pipes } & $f$ & 67 & 54 & 146 & 48 & 8 & 323 & & 30 & 12 & 33 & 3 & 2 & 77 & & & \\
\hline & $f x$ & 335 & 216 & 438 & 96 & 8 & 1093 & 3.38 & 150 & 48 & 99 & 6 & 2 & 305 & 3.96 & $\mathrm{CV}>\mathrm{DV}$ & 1 \\
\hline \multirow[t]{2}{*}{ Non-functional boreholes } & $f$ & 183 & 80 & 47 & 13 & 0 & 323 & & 52 & 13 & 7 & 5 & 0 & 77 & & & \\
\hline & $f x$ & 915 & 320 & 141 & 26 & 0 & 1402 & 4.34 & 235 & 52 & 21 & 10 & 0 & 318 & 4.12 & $\mathrm{CV}>\mathrm{DV}$ & 1 \\
\hline \multirow{2}{*}{ Corruption } & $f$ & 278 & 45 & 0 & 0 & 0 & 323 & & 70 & 7 & 0 & 0 & 0 & 77 & & & \\
\hline & $f x$ & 1390 & 180 & 0 & 0 & 0 & 1570 & 4.86 & 350 & 28 & 0 & 0 & 0 & 378 & 4.90 & $\mathrm{CV}>\mathrm{DV}$ & 1 \\
\hline \multirow{2}{*}{ Untrained Staff } & $f$ & 187 & 97 & 21 & 10 & 8 & 323 & & 45 & 19 & 8 & 4 & 1 & 77 & & & \\
\hline & $f x$ & 935 & 388 & 63 & 20 & 8 & 1414 & 4.37 & 225 & 76 & 24 & 8 & 1 & 363 & 4.71 & $\mathrm{CV}>\mathrm{DV}$ & 1 \\
\hline \multirow{2}{*}{ Meeting water demands is easy } & $f$ & 2 & 5 & 15 & 301 & 0 & 323 & & 0 & 0 & 1 & 76 & 0 & 77 & & & \\
\hline & $f x$ & 10 & 15 & 45 & 602 & 0 & 672 & 2.08 & 0 & 0 & 3 & 152 & 0 & 155 & 2.01 & $\mathrm{CV}<\mathrm{DV}$ & 0 \\
\hline
\end{tabular}


Table 10: Measures to ameliorate the challenges of water supply in study area

\begin{tabular}{|c|c|c|c|c|c|c|c|c|c|c|}
\hline \multirow[t]{2}{*}{ Measure } & \multicolumn{8}{|c|}{ Communities } & \multirow{2}{*}{$\begin{array}{l}\text { Remark } \\
\text { DV = 3 }\end{array}$} & \multirow{2}{*}{ Decision } \\
\hline & & SA & $\mathbf{A}$ & D & SD & $\mathbf{U}$ & $\Sigma$ & $\mathrm{CV}$ & & \\
\hline \multirow{2}{*}{ Adequate funding } & $f$ & 192 & 123 & 60 & 23 & 2 & 400 & & & \\
\hline & $f x$ & 960 & 492 & 180 & 46 & 2 & 1680 & 4.2 & $\mathrm{CV}>\mathrm{DV}$ & 1 \\
\hline \multirow{4}{*}{$\begin{array}{l}\text { Proactive maintenance and preventive } \\
\text { measures } \\
\text { Training and retraining of Staff }\end{array}$} & $f$ & 150 & 100 & 80 & 60 & 10 & 400 & & & \\
\hline & $f x$ & 750 & 400 & 240 & 120 & 10 & 1520 & 3.8 & $\mathrm{CV}>\mathrm{DV}$ & 1 \\
\hline & $f$ & 111 & 79 & 119 & 63 & 28 & 400 & & & \\
\hline & $f x$ & 555 & 316 & 357 & 126 & 28 & 1382 & 3.5 & $\mathrm{CV}>\mathrm{DV}$ & 1 \\
\hline \multirow[t]{2}{*}{ Proper security at equipment sites } & $f$ & 187 & 123 & 53 & 27 & 10 & 400 & & & \\
\hline & $f x$ & 935 & 492 & 159 & 54 & 10 & 1650 & 4.1 & $\mathrm{CV}>\mathrm{DV}$ & 1 \\
\hline \multirow{4}{*}{$\begin{array}{l}\text { Sensitization on how to use provided } \\
\text { facility } \\
\text { Provision of pipe-borne water }\end{array}$} & $f$ & 192 & 123 & 60 & 20 & 5 & 400 & & & \\
\hline & $f x$ & 960 & 492 & 180 & 40 & 5 & 1677 & 4.2 & $\mathrm{CV}>\mathrm{DV}$ & 1 \\
\hline & $f$ & 250 & 99 & 37 & 10 & 4 & 400 & & & \\
\hline & $f x$ & 1250 & 396 & 111 & 20 & 4 & 1781 & 4.5 & $\mathrm{CV}>\mathrm{DV}$ & 1 \\
\hline \multirow[t]{2}{*}{ Subsidized water rate } & $f$ & 129 & 140 & 67 & 54 & 10 & 400 & & & \\
\hline & $f x$ & 645 & 560 & 201 & 108 & 10 & 1524 & 3.8 & $\mathrm{CV}>\mathrm{DV}$ & 1 \\
\hline \multirow[t]{2}{*}{ Provision of clean water } & $f$ & 300 & 100 & 0 & 0 & 0 & 400 & & & \\
\hline & $f x$ & 1500 & 400 & 0 & 0 & 0 & 1900 & 4.8 & $\mathrm{CV}>\mathrm{DV}$ & 1 \\
\hline \multirow[t]{2}{*}{ Provision of functioning boreholes } & $f$ & 183 & 169 & 32 & 16 & 0 & 400 & & & \\
\hline & $f x$ & 915 & 676 & 96 & 32 & 0 & 1719 & 4.3 & $\mathrm{CV}>\mathrm{DV}$ & 1 \\
\hline \multirow[t]{2}{*}{ Meeting water demand is easy } & $f$ & 5 & 10 & 30 & 355 & 0 & 400 & & & \\
\hline & $f x$ & 25 & 40 & 90 & 710 & 0 & 865 & 2.1 & $\mathrm{CV}<\mathrm{DV}$ & 0 \\
\hline
\end{tabular}

SA: Strongly Agree, A: Agree, D: Disagree, SD: Strongly Disagree, U: Undecided, CV: Computed Value, DV: Derived Value; $0=$ Measure DOES NOT ameliorate, $1=$ Measure ameliorates; $\Sigma=$ summation.

\begin{tabular}{|c|c|c|c|c|}
\hline Subject Matter & Null Hypothesis & $\mathrm{CV}$ & Decision & Answer to Research Question \\
\hline $\begin{array}{l}\text { Challenges of regular } \\
\text { water supply }\end{array}$ & $\begin{array}{l}\text { There is no significant difference in the challenges } \\
\text { to the regular supply of water between urban and } \\
\text { rural areas in the study area }\end{array}$ & 4.1 & $\begin{array}{l}\text { Reject null } \\
\text { hypotheses }\end{array}$ & $\begin{array}{l}\text { There are significant challenges to regular supply between } \\
\text { urban and rural areas in the study area. }\end{array}$ \\
\hline Meeting water demands & $\begin{array}{l}\text { There are no significant differences in challenges to } \\
\text { meeting the water demands in the study area. }\end{array}$ & 2.1 & $\begin{array}{l}\text { Accept null } \\
\text { hypothesis }\end{array}$ & $\begin{array}{l}\text { There are no significant differences in challenges to meeting } \\
\text { the water demands between urban and rural areas in the study } \\
\text { area }\end{array}$ \\
\hline $\begin{array}{l}\text { Measures taken to } \\
\text { ameliorate inadequate } \\
\text { supply }\end{array}$ & $\begin{array}{l}\text { There is no gignificant difference in measures to } \\
\text { mitigate the challenges to ungafe water supply } \\
\text { between urban and rural areas in the study area. }\end{array}$ & 3.8 & $\begin{array}{l}\text { Reject null } \\
\text { hypothesis }\end{array}$ & $\begin{array}{l}\text { There are significant differences in measures employed to } \\
\text { mitigate the challenges of unsafe water supply between urbam } \\
\text { and rural areas in the study area }\end{array}$ \\
\hline $\begin{array}{l}\text { Seasonality challenges to } \\
\text { safe water. }\end{array}$ & $\begin{array}{l}\text { Seasonality did not affect the availability of safe } \\
\text { water in the study area. }\end{array}$ & 4.3 & $\begin{array}{l}\text { Reject null } \\
\text { hypothesis }\end{array}$ & $\begin{array}{l}\text { Seasonality affects the availability of safe water between } \\
\text { urban and rural areas in the study area }\end{array}$ \\
\hline
\end{tabular}


None of the communities sampled used water sourced from burrow pits for domestic purposes but all obtained their water for drinking and cooking from water vendors in both dry and wet seasons. Conversely, water from streams and taps were not accessed domestically in the urban and rural areas, respectively. Wells and water trucks were also reported as good sources of domestic water supply all year round, except in Samaru and Sakadadi, in the dry and wet seasons, respectively. In the three urban communities, bore holes and taps were reliable sources of domestic water in both seasons whereas the same could be said for water sourced from bore holes for Kuffena but not Wusasa and Sakadadi, which lacked bore holes. None of the three rural communities assessed water from streams in the rainy season. Neither could they assess tap water in either of the seasons because taps were not installed. Expectedly, none of the communities were able to access water for domestic purposes from rainfall in the dry season instead water vendors emerged as the prominent source. Remarkably, well water was most used in the rural areas during the wet season while the water vendors prevailed in the urban areas. In view of the unsafe nature of most of the water sources in the communities under study, the different methods of purification employed by the residents were examined and collated in Table 8 . The results indicated that both urban and rural settlements in Zaria used similar methods, such as alum coagulation, boiling, filtering and decanting, to purify water for domestic uses. However, the chlorination method was found among the urban dwellers whereas the use of iodine or ultraviolet light was not reported. Boiling was the most common method of purification employed by the residents followed by filtration. The challenges facing the supply of water to the residents in the study area were also examined (Table 9). Salient parameters, such as finance, distance to water sources and corruption, etc., were investigated to determine if they were aiding or abating access to water supply in the area. The results showed that the respondents thought that all the parameters examined were challenging and could therefore affect water supply

Both urban and rural settlements were in agreement that meeting water demands was not easy $(\mathrm{CV}=2.08$ $\& 2.01)$ and that corruption was a big challenge ( $\mathrm{CV}=$ $4.86 \& 4.90)$. This is exemplified by the unavailability of government bore holes in bore hole designated areas. The urban and rural communities opined that inadequate government funding and seasonal fluctuations were the next challenging parameters to water supply, respectively; next to corruption. Ocheri (2006) found that, in Nigeria, water scarcity was common, and attributed it to an unreliable, intermittent and, in most cases, inaccessible public water supply. This results in a high dependency on unsafe supplementary sources of water supply, which are susceptible to water-borne diseases, such as dysentery and cholera. Finance posed a challenge to water supply in urban and rural areas sampled because most of the respondents were not financially empowered to sink personal boreholes and therefore resorted to water hawkers, popularly known as "Mai Ruwa", who peddled their wares in 20-litre containers. Equally challenging to all the communities was the distance to and from the sources of water as many of them surpassed the WHO's (2014) maximum benchmark of $1 \mathrm{~km}$ as well as the 30-minute prescribed benchmark. The seasonality of water supplies also proved challenging to both urban and rural dwellers as the shortage of water was typically more pronounced in the dry season.

It is instructive that both rural and urban respondents thought that damaged pipes were the least challenging of the parameters evaluated. Damaged pipes restrict water supply, which can lead to shortages and wastes. Nonetheless, burst pipes can serve as sources of water supply to some residents who converge at the sites of damage to collect water from such pipes. When the pipes go dry; without water, however, they typically collect debris and dirt, which block these pipes, causing further damage. Other concurrences between the urban and rural communities sampled included untrained staff, distance and lack of maintenance.

Respondents were also asked to agree or disagree with a selected number of measures geared towards ameliorating the challenges posed by inadequate water supply in the communities sampled. Their responses were weighed using the Likert scale and enumerated in Table 10. With all the computed values (CV) greater than the derived value (DV) of 3 , it is logical to conclude that the measures outlined, if implemented, would improve water supply in the area under study. All the respondents agreed that the provision of clean water $(\mathrm{CV}=4.8)$ was the best solution but, surprisingly, suggested that retraining staff $(\mathrm{CV}=3.5)$ would not ameliorate the challenges of water supply in the study area.

In Table 11, the null hypotheses and answers to the research questions are tabulated. Three of the four null hypotheses were rejected based on their CV scores, which were $>3$ and, therefore, significant. The null hypothesis on meeting water demands was the only one accepted, with a CV of 2.1; concluding that there were no significant differences in challenges to meeting the water demands between urban and rural areas in the study area. The data generated agrees that 
there were significant challenges to regular water supply and differences in the measures employed to mitigate the challenges of unsafe water supply between urban and rural areas in the study area. Seasonality was also shown to affect the availability of safe water between the urban and rural communities sampled in the study.

\section{Conclusion}

It has been shown that access to safe, potable water is fraught with many but similar challenges in both rural and urban communities of Zaria. The inadequate access to safe supply sources has led to residents seeking easy ways of purifying their water for domestic use. The adoption of proactive maintenance and preventive measures, proper security at water equipment sites and subsidized water rates to disadvantaged communities as well as the provision of adequate sensitization on facility usage, mechanism for the regular monitoring of water quality and a nationwide water quality database should augur well for access to safe and potable water.

\section{REFERENCES}

Abaje, IB; Ati, OF; Ishaya, S (2009). Nature of Potable Water Supply and Demand in Jema'a LGA of Kaduna State, Nigeria. Res. J. Environ. Earth Sci. 1(1): 16-21.

Ahile, SI; Udoumoh, EF; Adzande, P (2015). Residents Coping Strategies with Water Scarcity in Makurdi Town, Nigeria. Mediterr. J. Soc. Sci. 6(4): S2.

Allan, JA (2010). Prioritizing the Processes Beyond the Water Sector that will Secure Water for Society-Farmers, Fair International Trade and Food Consumption and Waste (Rethinking Water and Food Security). Fourth Botín Foundation Water Workshop. CRC Press, Leyden, Netherlands. p. 93-106.

Appelgren, B; Klohn, W (1998). Management of Water Scarcity: A Focus on Social Capacities and Options. Land and Water Development Division. Food and Agricultural Organisation of the United Nations, Rome, Italy, 95pp.

Bello, NI; Tuna, F (2014). Evaluation of Potable Water Demand and Supply in Kano State, Nigeria. Inter. J. Sci. Knowl. 6(6): 35-42.

Bos, R; Alves, D; Latorre, C; Macleod, N; Payen, G; Roaf, V; Rouse, M (2016). Manual on the Human Rights to Safe Drinking Water and Sanitation for
Practitioners. IWA Publishing, London, UK, 120pp.

Cosgrove, WJ; Loucks, DP (2015). Water Management: Current and Future Challenges and Research Directions. Water Resour. Res. 51(6): 4823-4839.

Ezenwaji, EE; Anyaeze, E; Otti, VI; Obienusi, EA (2014). Mainfestations of Water Supply Shortages and Implication for Rural Development in Anambra State, Nigeria. J. Environ. Sci. Water Resour. 3(7): 149-155.

Falkenmark, M (2013). Growing Water Scarcity in Agriculture: Future Challenge to Global Water Security. Phil. Trans. R Soc. A 371(2002):

Falkenmark, M; Rockstrom, J (2004). Balancing Water for Human and Nature: The New Approach in Ecology, Earthscan Publication, London, 320pp.

Krejcie, R. V.; Morgan, D. W. (1970). Determining Sample Size for Research Activities. Educ. Psychol. Meas. 30(3): 607-610.

L'Vovich, MI; White, GF; Belyaev, AV; Kindler, J; Koronkevic, NI; Lee, TR; Voropaev, GV (1990). Use and Transformation of Terrestrial Water Systems. In: Turner II, BL; Clark, WC; Kates, RW; Richards, JF; Mathews, JT; Meyer, WB (eds). The Earth as Transformed by Human Action. Cambridge University Press, Cambridge, UK. p. 235-252.

Nigeria Metro Area Population (1950-2020). www.macrotrends.net (accessed August 2019).

Nura, AD; Sabo, M (2011). Determinants of Household Demand for Water in Kano Metropolis: A Crisis Sectional Analysis. Kano J. Arts Soc. Sci. 8(1): 20-31.

Ocheri, M; Ahola, O; Atu, B (2012). Profile of Water Related Diseases in Benue State, Nigeria. Am. J. Hum. Ecol. 1(3): 87-94.

Oyebande, L (2001). Water Problems in Africa-How Can the Sciences Help? Hydrol. Sci. J. 46(6): $947-$ 962.

Postel, S (2000). Entering an Era of Water Scarcity: The Challenges Ahead. Ecol. Appl. 10(4): 941948. 
Postel, SL; Daily, GC; Ehrlich, PR (1996). Human Appropriation of Renewable Fresh Water. Science 271(5250): 785-788.

Schyns, JF; Hoekstra, AY; Booij, MJ (2015). Review and Classification of Indicators of Green Water Availability and Scarcity. Hydrol. Earth Syst. Sci. 19(11): 4581-4608.

Tasi'u, YR; Iguisi, EO; Mallam, I (2016). Assessment of Water Supply Situation in the Rural Areas of Kano State, Northern Nigeria. Glo. Adv. Res. J. Agric. Sci. 5(1): 33-41.

[UNESCO] United Nations Educational, Scientific and Cultural Organisation (2016). Water and Jobs: United Nations World Water Development Report. UNESCO, Paris, France. 164pp.

United Nations Sustainable Development Goals 6 (SDG-6)

https://www.un.org/sustainabledevelopment/water -and-sanitation/ (accessed September 2021)

[UN] United Nations Organisation (2011). The Millennium Development Goals Report 2011. United Nations Organisation, New York, US. $72 \mathrm{pp}$.

UN-Water (2006) Coping with Water Scarcity: A Strategic Issue and Priority for System-Wide Action. United Nations Water Thematic Initiatives (www.unwater.org). United Nations Organisation, New York, US. 12pp. https://www.un.org/waterforlifedecade/pdf/2006_ unwater_coping_with_water_scarcity_eng.pdf
UN-Water (2007). Coping with Water Scarcity Challenge of the 21st Century. World Water Day 2007 (www.worldwaterday07.org). United Nations Organisation, New York, US. 29pp. http://www.fao.org/3/aq444e/aq444e.pdf

Ward, RC; Robinson, M (2000). Principles of Hydrology, $4^{\text {th }}$ edn. McGraw-Hill, London, UK. 450pp.

WHO/UNICEF] World Health Organisation/United Nations Educational, Scientific and Cultural Organisation (2000). Global Water Supply and Sanitation Assessment 2000 Report. WHO/UNICEF, Geneva/New York. 39pp.

World Bank (1996). Nigeria: Poverty in the Midst of Plenty - The Challenge of Growth with Inclusion. Population and Human Resources Division, West Africa Department, World Bank, Washington, DC. 176pp.

[WPR] World Population Review (2021). https://worldpopulationreview.com/worldcities/zaria-population (accessed August 2021).

$\mathrm{Xu}, \mathrm{Y}$; Usher, BH (2006). Issues of Groundwater Pollution in Africa. In: Xu, Y; Usher, BH (eds). Groundwater pollution in Africa (United Nations Environment Programme). Taylor \& Francis/Balkema, Leiden, Netherlands. p. 3-13.

Yakubu, S (2013). Assessment of Water Quality of Hand-Dug Wells in Zaria LGA of Kaduna State, Nigeria. Inter. J. Eng. Sci. 2(11): 1-4. 